\title{
Effect of feeding level on dry matter degradation characteristics of canola meal and soybean meal
}

M Pourabedin, A Afzalzadeh, A A Khadem

University of Tehran, Aburaihan Campus, Tehran, Islamic Republic of Iran

Email:mohsen@pourabedin.com

Introduction In general, an increase in the level of feeding of a basal diet results in a decrease in digestion due to a shorter retention time of feed in the rumen. Many trials have examined the effect of feeding various hay to concentrate rations on disappearance values of concentrate feedstuffs but experiments on the effect of feeding level on digestibility of feedstuffs are limited and contradictory. Even though relationships between intake level and in situ degradation can be theorized, actual studies of such relationships are lacking (Vanzant et al, 1998). Our study was designed to examine the effect of feeding level (FL) on disappearance kinetics of dry matter (DM) of canola meal and soybean meal which are the most widely used protein sources in animal feeds.

Materials and methods Four Iranian shal wethers with a body weight of $40 \pm 2 \mathrm{~kg}$ ( 2 years old) were used in this study. Sheep were each fitted with a rumen fistula (4 cm internal diameter) and kept in individual stainless steel cages with external feed and water troughs. A diet was offered at four levels of feeding: 1 (maintenance), 1.5, 2 and 2.5 times of the maintenance requirements. The sheep were fed twice daily (08 and $14 \mathrm{~h}$ ) a diet containing $600 \mathrm{~g} / \mathrm{kg}$ concentrate and 400 $\mathrm{g} / \mathrm{kg}$ forage. Animals were fed these diets 15 days before the experimental periods. Ruminal kinetic parameters were estimated using the exponential equation of Ørskov and McDonald (1979). Nylon bags (which were approximately $6 \times 12$ $\mathrm{cm}, 45 \mu \mathrm{m})$ containing $5 \mathrm{~g}(2 \mathrm{~mm}$ screen) of samples were incubated in the rumen for $0,4,8,16,24,48$ and $72 \mathrm{~h}$. After incubation times the nylon bags removed and washed in tap water until the water remained clear. There were four replications per treatment (FL). The rate and extent of dry matter (DM) degradation were estimated according to the equation: $\mathrm{P}=\mathrm{a}+\mathrm{b}\left(1-\mathrm{e}^{-\mathrm{ct}}\right)$. The experiment consisted of four periods. During the first period, the ruminal degradability of concentrate samples as measured at maintenance level of intake in all four animals, and during the second, third and fourth periods, respectively, the ruminal degradability calculated at 1.5, 2 and 2.5 times of maintenance. Data were analyzed using the general linear models procedure of SAS (1996). When a significant difference was found, means were separated using Duncan test. Differences were considered to be significant if $\mathrm{P}<0.01$.

Result table 1 shows that feeding level had a significant effect on in situ DM degradation characteristics. The increase of feeding level induced a decrease in the value of $a, b$ and effective degradability (ED) $(p<0.01)$. Both the fraction $b$ and ED were significantly $(\mathrm{p}<0.01)$ higher for the $\mathrm{FL}=1$ than for other treatments.

Table 1 Influence of feeding level on ruminal kinetic of DM of canola meal and soybean meal

\begin{tabular}{lccccc}
\hline \hline Intake $^{\mathrm{l}}$ & $\mathrm{a}$ & $\mathrm{b}$ & $\mathrm{c}$ & $\mathrm{PD}(\%)$ & $\mathrm{ED}(\%)$ \\
\hline Canola meal & & & & & \\
1 & $35.0^{\mathrm{a}}$ & $47.8^{\mathrm{a}}$ & $0.044^{\mathrm{c}}$ & $82.9^{\mathrm{a}}$ & $68.0^{\mathrm{a}}$ \\
1.5 & $36.8^{\mathrm{a}}$ & $45.1^{\mathrm{b}}$ & $0.041^{\mathrm{d}}$ & $81.9^{\mathrm{a}}$ & $67.2^{\mathrm{b}}$ \\
2 & $33.3^{\mathrm{b}}$ & $43.3^{\mathrm{c}}$ & $0.064^{\mathrm{b}}$ & $76.6^{\mathrm{b}}$ & $66.3^{\mathrm{c}}$ \\
2.5 & $32.5^{\mathrm{b}}$ & $39.8^{\mathrm{d}}$ & $0.070^{\mathrm{a}}$ & $72.3^{\mathrm{c}}$ & $63.5^{\mathrm{d}}$ \\
Significance & $* *$ & $* *^{\mathrm{b}}$ & $* *$ & $* *$ & $* *$ \\
SEM & 0.45 & $0.7^{\mathrm{a}}$ & 0.003 & 1.03 & 0.43 \\
Soybean meal & & & & & \\
1 & $35.9^{\mathrm{a}}$ & $61.5^{\mathrm{b}}$ & $0.034^{\mathrm{c}}$ & $97.5^{\mathrm{a}}$ & $74.6^{\mathrm{b}}$ \\
1.5 & $30.9^{\mathrm{b}}$ & $64.5^{\mathrm{a}}$ & $0.044^{\mathrm{a}}$ & $95.4^{\mathrm{b}}$ & $75.3^{\mathrm{a}}$ \\
2 & $35.8^{\mathrm{a}}$ & $53.1^{\mathrm{c}}$ & $0.037^{\mathrm{b}}$ & $88.9^{\mathrm{c}}$ & $70.4^{\mathrm{c}}$ \\
2.5 & $31.2^{\mathrm{b}}$ & $52.2^{\mathrm{d}}$ & $0.045^{\mathrm{a}}$ & $83.4^{\mathrm{d}}$ & $67.4^{\mathrm{d}}$ \\
Significance & $* *$ & $* *$ & $* *$ & $* *$ & $* *$ \\
SEM & 0.29 & 0.27 & 0.0004 & 0.24 & 0.22 \\
\hline \hline
\end{tabular}

1: Multiple of maintenance requirement

a: soluble fraction (\%); b: insoluble but potentially degradable fraction (\%); c: fractional rate of degradation (h-1); PD: Potential of degradation; ED: Effective degradability

Conclusion As expected, an increased FL resulted in a decreased potential of degradation. We concluded that the b fraction of canola meal and soybean meal decreases with increasing FL. The results of this experiment also indicate an important effect of FL on other degradability parameters "a" and "c". Therefore, altering energy intake plays a major role in digestibility of forages, so feeding level should be considered in feed evaluation systems and feed formulation.

\section{References}

Ørskov, E. R., McDonald, I. 1979. The estimation of protein disappearance in the rumen from incubation measurements weighted according to rate of passage. Journal of Agricultural Science, Cambridge 92, 499-503.

Vanzant E. S., Cochran, R. C., Titgemeyer, E. C. 1998. Standardization of in situ techniques for ruminant feedstuff evaluation. Journal of Animal Science, 76, 2717-2729. 